\title{
Evaluation System of Kemuhammadiyahan in Universitas Muhammadiyah Sumatera Barat
}

\author{
Ilpi Zukdi ${ }^{1, *}$, Sufyarma Marsidin ${ }^{2}$, Dasman Lanin ${ }^{3}$, Alizamar $^{4}$ \\ ${ }^{1}$ Department of Islamic Education, Faculty of Tarbiyah and Teacher Training, Universitas Islam Negeri Imam Bonjol, \\ Padang, Indonesia \\ ${ }^{2}$ Department of Educational Administration, Faculty of Education, Universitas Negeri Padang, Padang, Indonesia \\ ${ }^{3}$ Department of Public Administration, Faculty of Social Sciences, Universitas Negeri Padang, Padang, Indonesia \\ ${ }^{4}$ Department of Counseling Guidance, Faculty of Education, Universitas Negeri Padang, Padang, Indonesia \\ *Email: ilpi1007@yahoo.com
}

\begin{abstract}
Kemuhammadiyahan is compulsory education given to all Muhammadiyah environment. Here, the function of education is as tool to serve society, to educate leafrners amar makruf nahi munkar and to form caders. This function is always developed to reach the perspective of Muhammadiyah education. Like religious learners, good character, better in science, art and technology as a form of amar makruf nahi munkar. Forms of this education are in intelectual development and learners identify. So, Kemuhammadiyahan is not just for science but also for learners attitude in their daily life. Finding of this research shows that to determine the level of learner's achievement, yhe lectures had evaluated it. But, this is just for cognitive ability between mid and the last semester. This research is hoped to complete the evaluation system in Kemuhammadiyahan. As a result the perspective of Muhammadiyah education can be reached.
\end{abstract}

Keywords: Kemuhammadiyahan, evaluation, student

\section{INTRODUCTION}

The basic problem in the evaluation of learning Kemuhammadiyahan is to prioritize learning outcomes in the cognitive aspects. The cognitive aspect tends to produce students who have religion and lack of learning independence, so it does not produce effective outcomes. According to Marzano, Pickering, \& McTighe[1] to produce effective comes out there are five dimensions that must be considered, viz a. Possitive Attitude \& Perception about Learning, b. Acquiring \& Integrating Knowledge, c. Extending \& Refining Knowledge, d. Using Konwledge Meaning Fully, e. Productive Habits of Mind.

In the fifth step (e. Productive Habits of Mind), students who already feel that learning is a necessity, develop what is important for their lives, always look for propositions and evidence of something, always evaluate so that activities become more effective and never give up of problems that cannot yet be overcome, then he has become a successful learner. This means that evaluation is not only limited to cognitive aspects but also to the affective and psychomotor aspects. In the 2012 Chapter I Muhammadiyah Higher Education Guidelines, article 1 paragraph 4 emphasizes that the Muhammadiyah must be imbued and based not only on the ideologicalphilosophical level alone but also practically and applicatively so that it becomes one of the forces for the continuation and continuity of Muhammadiyah in achieving its goals as propaganda and tajdid movements across the ages.

Based on the description in the paragraph above, then educators at the Kemuhammadiyahan course are required to develop and improve the quality of learning both learning models, teaching materials, media, strategies and evaluations that are in accordance with the characteristics of the Muhammadiyah Center [2], [3].

With regard to evaluations, educational experts vary in providing limits. Fitzpatrick, Sanders, \& Worthen[4] evaluation is: "identification, clarification, and application of defensible criteria to determine an evaluation object's value (worth or merit) in relation to those criteria". In connection with these criteria Gronlund \& Linn[5] states that evaluation is "the systematic process of collecting, analyzing, and interpreting information to determine the extent to which pupils are achieving instructional objectives". Meanwhile Nitko[6] simply said that evaluation is: "a decision-making process for students".

The definitions stated by the experts above give an understanding that evaluation is an activity comparing what has been achieved in learning with what should be achieved based on established criteria/standards. Harlen[7] explains, the terms that are often used in educational evaluation activities are assessment and evaluation, both have different meanings. Further said that: The terms "evaluation" and assessment in education are sometimes used with different meanings, but also interchangeably. In some countries, including the USA, the term "evaluation" is often used to refer to individual student 
achievement, which in other countries including the UK is described as "assessment"..."assessment" refers to the process of collecting evidence and making judgments relating to outcomes, such as students achievement of particular goals of learning or teacher and others understanding. Meanwhile Griffin \& Nix[8] states that: Measurement, assessment and evaluation are hierarchical. The comparison of observation with the criteria is a measurement, the interpretation and description of the evidence is an assessment and the judgment of the value or implication of the behavior is an evaluation.

Referring to the opinion of Griffin \& Nix[8] above, it can be explained that measurement, evaluation and evaluation are hierarchical. Evaluation is preceded by assessment, while assessment is preceded by measurement. Measuring is the activity of comparing observations with criteria, while assessment is an activity of interpreting and describing measurement results, evaluation is the determination of values or behavioral implications.

The explanation above gives an understanding that evaluation is inherent in the learning process. There are three areas that need to be evaluated by educators in learning, namely cognitive, affective and psychomotor. Evaluation has the aim to determine the success of learning for each student. Learning success has important meaning because it will be a benchmark for students to continue to the next level or not.

Evaluation of the cognitive domain focuses on the ability of students to store knowledge in their memory and use it. In the cognitive realm, educators only measure the intellectual abilities possessed by each student. The affective domain requires changes in interests, attitudes and values in students. The affective domain also requires students to be able to develop an attitude of respect and be able to adjust to the surrounding environment. The psychomotor domain emphasizes more on the movements made by students. Movement can be in the form of coordination of muscles or limbs.

In learning, including learning Kemuhammadiyahan as a course in the context of forming academic people who are moral, character and Muslim personality (learning to be), then these three domains need to be applied in carrying out evaluations. The most urgent criterion for the success of this subject is the change in attitude, mentality and behavior of students. Keblowska[9] argues that: "the affective domain plays a very important role in the learning process ..."

\section{RESEARCH METHODS}

This research was designed in the form of qualitative research with a type of case study. This research was conducted at the University of Muhammadiyah, West
Sumatra. Research informants consisted of AIK lecturers as key informants and students at the Faculty of Economics, the Faculty of Islamic Religion and the Faculty of Forestry. The technique used in determining the informants in this study used snowball technique (snowball sampling).

Data collection is done by several techniques, namely: Observation; the researcher observes lecturers and students as well as the learning process and the implementation of the evaluation. Observation is directed at the implementation of evaluation activities. So that the observation is well directed, the researcher uses the observation sheet / guide to further make a field note.

Interview; The researcher conducted interviews with informants related to the implementation of the Kemuhammadiyahan evaluation. This technique is used to complement the data obtained by observation in order to obtain wider and more complete data. Data collection tools used were interview guides and tape recorders as data recording devices.

Documentation; researchers studied several documents related to evaluation instruments. Data collection is done by a qualitative approach. Therefore this data analysis is in accordance with qualitative research which is a cycle [10]. Thus it can be said that data analysis activities cannot be separated from data collection activities [11].

The next data analysis is to use descriptive techniques as recommended by Miles and Huberman[12], namely by performing data reduction, data presentation, and drawing conclusions.

Checking the validity of the data in this study uses four criteria as suggested by Lincoln \& Guba[13] and Sugiyono[10], namely: (1) credibility (internal validity), (2) tranferability (external validity), (3) dependability (reliability), and (4) confirmability (objectivity).

\section{RESULTS AND DISCUSSION}

\subsection{Results}

Based on the results of data collection that has been done at the Universitas Muhammadiyah Sumatera Barat, all faculties have conducted an evaluation. There are two evaluation activities, namely in the middle and end of the semester. The midterm evaluation is carried out after eighty-one meetings are held in class and the ninth meeting is held in the midterm evaluation. The evaluation at the end of the semester is carried out after the face-toface meeting was completed 15 times.

To see the evaluation process that has been running can be described as follows: 


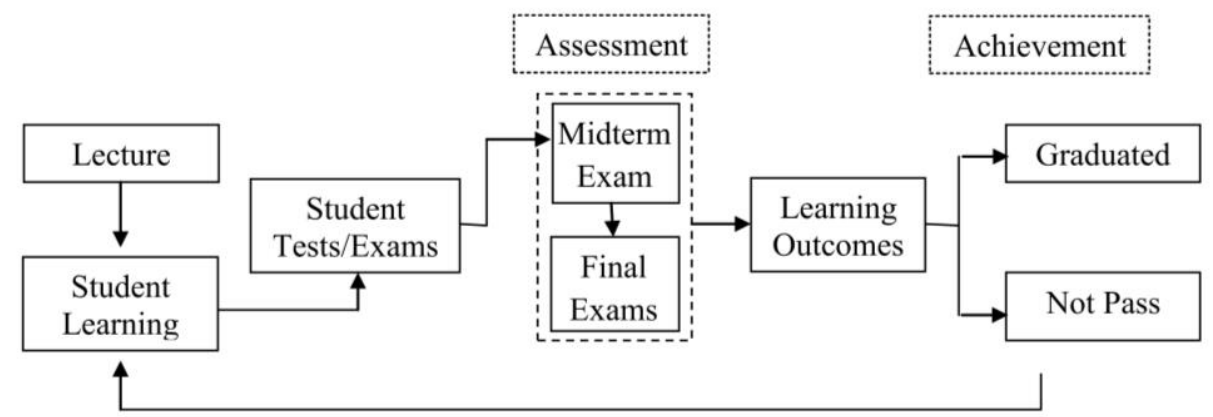

Picture 1 The process of evaluating Kemuhammadiyahan at Universitas Muhammadiyah Sumatera Barat

Based on the picture above it can be seen, the orientation of the evaluation of Kemuhammadiyahan is to the mastery of the material that has been taught by conducting a written test. There are two possibilities for learning outcomes, namely graduating and not graduating. For students who do not graduate, they must repeat the same semester the following year.

Based on interviews and observations supported by documentation, the evaluation instruments are all in the form of written tests that are more focused on the cognitive realm. This means that all material in the evaluation contains questions about the extent to which students know about the material that has been given. Therefore, the evaluation only measures the intellectual abilities possessed by each student both on the Midterm Examination and on the Final Semester Examination.

\subsection{Discussion}

From the results of the above research it can be seen that the evaluation that has been running on the Kemuhammadiyahan course at Muhammadiyah University, West Sumatra consists of mid and end semester evaluations. Both of these evaluations only focus on the cognitive realm.

As a special subject that contains a mission, of course, it is not only enough to measure the intellectual abilities possessed by students. But further than that makes this course to form his attitude. Rosevelt in Lickona[14] asserts that: educating someone on their minds and not on morals is the same as educating someone who has the potential to be a threat to society. This means that if only intellectual intelligence is concerned without being accompanied by moral values, it will not benefit itself, the environment, society, nation and state.

Kilpatrick in Lickona[14] argues that the fundamental problem faced by schools today is moral. Other problems stem from this problem. This affirms that education has a very strategic position in the formation of values in students. According to Brady[15] what is shown by students in the midst of the community is a reflection of the educational process that he obtained while at school. Therefore in the education process the formation of values for students becomes something urgent.

Value is a general principle, which provides community members with a certain size or standard to make judgments and choices about certain actions and ideals [16]. Values are preferences that are preferred both regarding social relations and about ideals and efforts to achieve them [17].

In Law No. 20 of 2003 concerning the National Education System explicitly contains hopes that future generations possess: spiritual, religious, self-control, personality and noble character. To realize this the government emphasizes character education. Hidayati, Zaim, Rukun, \& Darmansyah[18] argues that the purpose of character education is to build students who are experienced, have skills and noble attitudes so that they are able to compete in the face of globalization.

Thus it can be said that attitude is one of the most important elements in preparing students to compete in the future, because according to Fishbean \& Ajzen[19] attitude is an inclination to respond consistently to things that are likes or dislikes of an object. The responses given or shown can be either verbal or non-verbal responses. Elfindri et al[20] argue that when talking about affective or attitude, there are several dimensions that need to be understood, namely dimensions in the affective domain, among others, the dimensions of soft skills and character. The realm of soft skills is the process of forming attitudes that lead to the optimal functioning of knowledge and skills. While the formation of character, more to the formation of daily behavior in relation to items that can enter into this dimension.

Based on the descriptions that have been stated above it can be concluded that the measurement of affective domains is very much needed in the evaluation of the Kemuhammadiyahan course. Evaluation is not only on the results but also during the lecture process. For this reason, an evaluation system can be carried out as described below: 


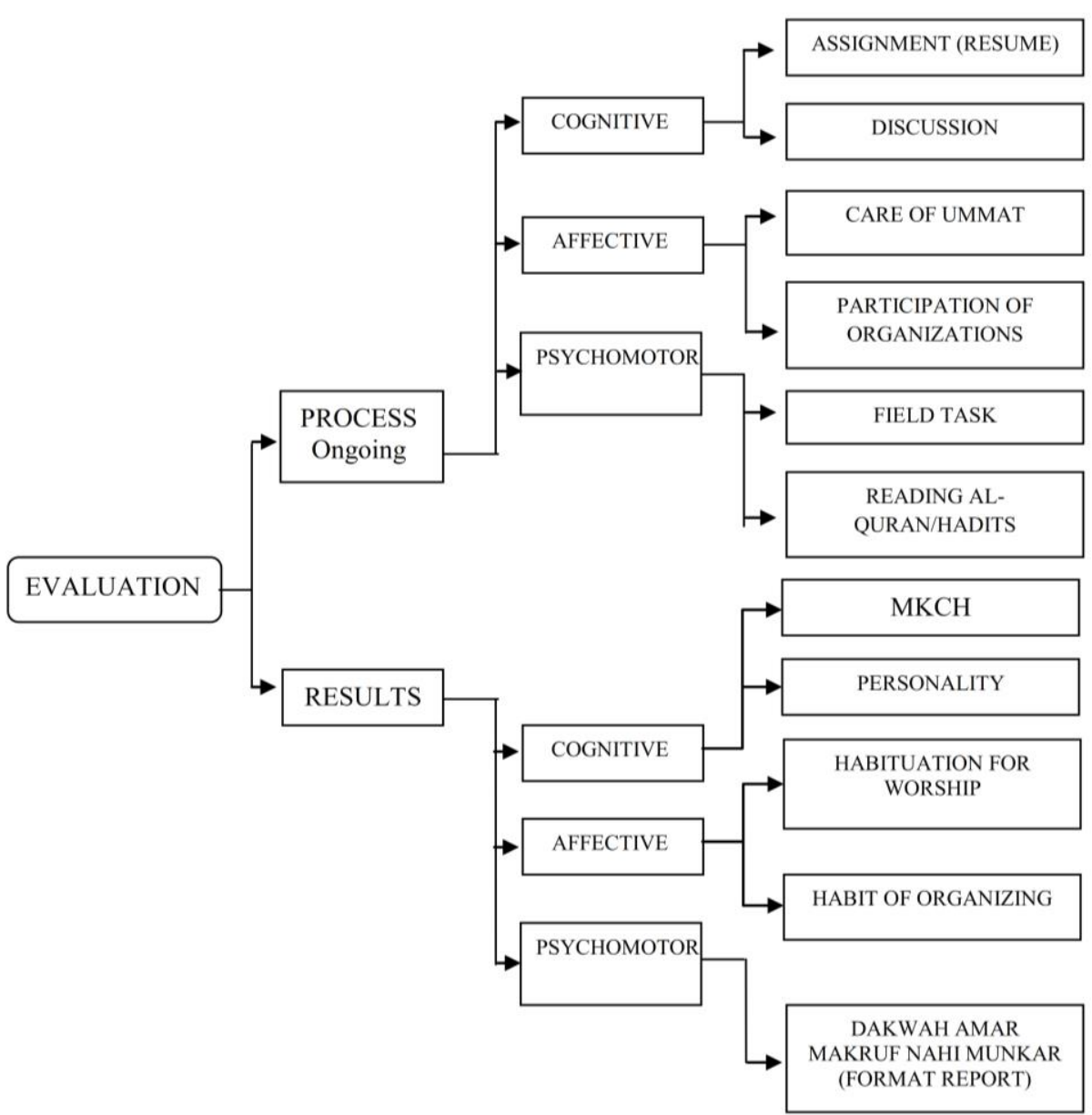

Picture 2 Schematics Evaluation System for the Kemuhammadiyahan Course

\section{CONCLUSION}

In this section conclusions will be made based on the results of research and discussion as described earlier. The conclusions referred to, namely 1) Evaluation of learning of the Kemuhammadiyahan course at Muhammadiyah University of West Sumatra was carried out in two forms, namely midterm and end of semester evaluations; and 2) The evaluation material is more focused on the cognitive domain while the affective and psychomotor domains have not been touched.

\section{REFERENCES}

[1] R. J. Marzano, D. Pickering, and J. McTighe, Assessing Student Outcomes: Performance Assessment Using the Dimensions of Learning Model. Alexandria: Mid-Continent Regional Educational Lab., Aurora, CO., 1993.

[2] I. Setiawan, "Pembelajaran Al-Islam dan Kemuhammadiyahan yang Menggembirakan (Dengan
Pendekatan Integrasi-Interkoneksi)," in Prosiding Seminar Nasional Al-Islam dan Kemuhammadiyahan, 2001, pp. 123-135.

[3] S. Arifin, "Rekonstruksi Al-IslamKemuhammadiyahan (AIK) Perguruan Tinggi Muhammadiyah sebagai Praksis Pendidikan Nilai," EDUKASI J. Penelit. Pendidik. Agama dan Keagamaan, vol. 13, no. 2, pp. 201-221, 2015.

[4] D. Darojat and W. M., "Model Evaluasi Program Pendidikan," Islamidina, vol. 14, no. 1, pp. 1-28, 2015.

[5] N. E. Gronlund and L. L. Robert, Measurement and Evaluation in Teaching, 6th ed. New York: Macmillan, 1990.

[6] R. Mohamed and O. Lebar, "Authentic Assessment in Assessing Higher Order Thinking Skills," Int. J. Acad. Res. Bus. Soc. Sci., vol. 7, no. 2, pp. 466-476, 2017.

[7] W. Harlen, Assessment of Learning. London: Sage Publication, 2007.

[8] P. Griffin and P. Nix, Educational Assessment 
and Reporting. Sydney: Harcout Brace Javanovich, Publisher, 1991.

[9] M. Keblowska, "The Place of Affect in Second Language Acquisition," in Second Language Learning and Teaching: New Perspective on Individual Differences in Language Learning and Teaching, M. Pawlak, Ed. New York: Springer Publishing Company, 2012.

[10] Sugiyono, Metode Penelitian Kuantitatif, Kualitatif dan R\&D, 15th ed. Bandung: Alfabeta, 2012.

[11] W. Mantja, Etnografi, Desain Penelitian Kualitatif Pendidikan dan Manajemen Pendidikan. Malang: Elang Mas, 2007.

[12] M. B. Miles and A. M. Huberman, Qualitative Data Analysis: A Sourcebook of New Methods. London: Sage Publications, 1987.

[13] Lincoln and Guba, Naturalistik Inquiri. Baverly Hills: Sage Publication, 1985.

[14] T. Lickona, Mendidik untuk Membentuk Karakter: Bagaimana Sekolah dapat Memberikan Sikap Hormat dan Tanggungjawab. Jakarta: Bumi Aksara, 2012.

[15] A. Brady, "Integrating the Spiritual-Cultural, Rights-Responsibilities, and Economics of a Citizenship Development Higher Learning through a Differently Conceived and Practiced Sociology in (Second Language) English in the Japanese University," Creat. Educ., vol. 4, no. 12 , pp. 75-82, 2013.

[16] Mustari, Nilai Karakter: Refleksi untuk Pendidikan. Jakarta: Raja Grafindo Persada, 2014.

[17] D. Darimis, "Revitalisation of Moral Values in Minangkabau Culture: Perspective Model of Reality Counseling," in Proceeding of the Third International Seminar on Languages and Arts, 2014, pp. 88-93.

[18] A. Hidayati, M. Zaim, K. Rukun, and D. Darmansyah, "The Development of Character Education Curriculum for Elementary Students in West Sumatera," Int. J. Educ. Res., vol. 2, no. 6, pp. 189-198, 2014.

[19] M. Fishbean and A. Icek, Belief, Attitude, Intention and Behavior: An Introduction to Theory and Research. California: Addison-Wesley Publishing Company, 1975.

[20] Elfindri, Pendidikan Karakter: Kerangka, Metode dan Aplikasi untuk Pendidikan dan Profesional. Jakarta: Baduose Media, 2012. 